\title{
Assessment of the cytotoxic, genotoxic, and antigenotoxic activities of Celtis iguanaea (Jacq.) in mice
}

\author{
FLAVIO F.V. BORGES ${ }^{1}$, THIAGO C. MACHADO ${ }^{1}$, KÊNYA S. CUNHA ${ }^{2}$, \\ KARLA C. PEREIRA ${ }^{2}$, ELSON A. COSTA ${ }^{3}$, JOSÉ R. DE PAULA ${ }^{4}$ and LEE CHEN-CHEN ${ }^{1}$ \\ ${ }^{1}$ Departamento de Biologia Geral, Instituto de Ciências Biológicas (ICB), \\ Universidade Federal de Goiás (UFG), Campus-II, 74001-970 Goiânia, GO, Brasil \\ ${ }^{2}$ Departamento de Bioquímica e Biologia Molecular, Instituto de Ciências Biológicas (ICB), \\ Universidade Federal de Goiás (UFG), Campus-II, 74001-970 Goiânia, GO, Brasil \\ ${ }^{3}$ Departamento de Ciências Fisiológicas, Instituto de Ciências Biológicas (ICB), \\ Universidade Federal de Goiás (UFG), Campus-II, 74001-970 Goiânia, GO, Brasil \\ ${ }^{4}$ Departamento de Tecnologia Farmacêutica, Faculdade de Farmácia, \\ Universidade Federal de Goiás (UFG), Campus-I, 74605-220 Goiânia, GO, Brasil
}

Manuscript received on September 2, 2011; accepted for publication on October 28, 2011

\begin{abstract}
Ethnobotanical surveys of Cerrado native plants show that leaves of Celtis iguanaea (Jacq.) Sargent (Cannabaceae), popularly known in Brazil as "esporão de galo", are used in folk medicine for body pain, asthma, cramps, poor digestion, urinary infection, kidney dysfunctions, as well as a stimulant and diuretic. This work aimed at evaluating possible $C$. iguanaea aqueous leaf extract (CALE) cytotoxicity, genotoxicity, and antigenotoxicity using the mouse bone marrow micronucleous test. To assess CALE genotoxicity, Swiss mice were orally treated with three different extract concentrations $\left(100,300\right.$, and $\left.500 \mathrm{mgkg}^{-1}\right)$. To evaluate its antigenotoxicity, the same doses were used simultaneously with a single i.p. dose of mitomycin C (MMC, $4 \mathrm{mg} \cdot \mathrm{kg}^{-1}$ ). The frequencies of micronucleated polychromatic erythrocytes (MNPCE) were evaluated $24 \mathrm{~h}$ and $48 \mathrm{~h}$ after administration except for the negative control $(24 \mathrm{~h})$. Genotoxicity was evaluated using the frequency of micronucleated polychromatic erythrocytes (MNPCE), whereas cytotoxicity was assessed by the polychromatic and normochromatic erythrocytes ratio (PCE/NCE). The results showed that CALE did not exhibit a significant reduction in the PCE/NCE ratio, neither a considerable increase in the frequency of MNPCE. Nonetheless, CALE reduced bone marrow toxicity (increased PCE/NCE ratio) and decreased the micronuclei frequency induced by MMC. We can conclude that CALE presented no cytotoxic and genotoxic effects, but showed antigenotoxic and anticytotoxic actions under the experimental conditions applied in this study.
\end{abstract}

Key words: Cytotoxicity, genotoxicity, mice, medicinal plant.

\section{INTRODUCTION}

The use of plant products for the treatment, cure, and prevention of general disorders is one of the earliest forms of medical practice, and probably

Correspondence to: Lee Chen-Chen

E-mail: chenleego@yahoo.com.br almost as old as the human species (Halberstein 2005). It is estimated that natural products and herbal preparations are responsible for $25 \%$ of the medical prescriptions in developed countries and about $80 \%$ in developing countries. The number of bioactive plant compounds exceeds 100,000, but 
the actual number must be much higher because only $20-30 \%$ of plants have been investigated so far (Wink 2009). Also, a significant number of synthetic drugs was obtained from natural precursors (Raskin et al. 2002, Rates 2001).

The Brazilian Cerrado is the richest savanna formation in the world, responsible for about $5 \%$ of global biodiversity, and considered one of the world's hotspots. (Myers et al. 2000). It has an endemic level of $44 \%$ for vascular plants and $70 \%$ for herbaceous plants, representing a valuable spectrum of organic molecules with medical and therapeutic potential (Machado et al. 2008).

Safety and toxicity studies of plants used in therapy are vital, due to its considerable range of applications and its widespread use in folk medicine, which, according to Maciel et al. 2002 , often represent the only therapy of many communities and ethnical groups.

In the Brazilian Cerrado traditional medicine, the leaf infusion of Celtis iguanaea (Jacq.) Sargent, popularly known as "esporão-de-galo" (Souza and Lorenzi 2005), is used in the treatment of body pains, asthma, colic, poor digestion, urinary infection, kidney dysfunctions, as well as a stimulant and diuretic (Carneiro 2009, Silva and Proença 2008, Piliackas et al. 2001). According to ethnobotanical surveys of the Cerrado native plants, this species showed a considerable consensus of popular usage (Silva and Proença 2008), which may indicate potential medical properties and strengthen the need of proper pharmacological and toxicological studies (Vendruscolo and Mentz 2006). However, despite the wide use of this plant, a rather scarce literature is dedicated to the species and little information regarding the biological effects of its constituents can be found, especially when it comes to their potential toxicological properties.

Several studies on phytotherapic substances have already reported that many medicinal plant compounds present undesirable properties, such as mutagenicity, carcinogenicity and toxicity, limiting their use as therapeutic agents (Déciga-Campos et al. 2007, Marques et al. 2003). On the other hand, a number of studies have also shown that phytotherapic compounds may possess antigenotoxic/ anticarcinogenic effects (Aruoma 2003, Gupta et al. 2001, Waters et al. 1996). Therefore, the investigation of traditionally used medicinal plants is valuable both as a source of potential chemotherapeutic drugs, and as a measure of safety for the continuous use by the population (Verschaeve et al. 2004).

Short-term assays have been used for more than 30 years to identify chemical, physical, and biological genotoxic agents, as well as to assess their carcinogenic potential. Although the genetic toxicity is not a direct measure of carcinogenicity, it is often used as an indicator for cancer, since genotoxicity tests measure an initial or intermediary event in tumorigenesis (Fearon and Volgelstein 1990).

Among the methods for in vivo genotoxicity investigation, the micronucleus test has been widely accepted by regulatory agencies and governmental institutions (Mateuca et al. 2006, Choy 2001). This assay was initially developed in mouse bone marrow erythrocytes (Schmid 1975). Since then, it has been used to assess the genotoxic potential of physical and chemical agents (Ding et al. 2003, Chung et al. 2002), biomonitor human populations occupationally exposed to mutagens (Bolognesi et al. 2004, Majer et al. 2001), in the search for carcinogenesis inhibiting compounds (Roy et al. 2003, Izzotti et al. 2001), and in ecotoxicological studies (Llorente et al. 2002, Gauthier et al. 1999).

The micronucleus test detects genetic alterations arising from chromosomal damage and/or damage to the mitotic apparatus caused by clastogenic or aneugenic agents, respectively. As micronuclei (MN) are indicative of irreversible DNA loss, their frequency may be used as a mutation index (Azevedo et al. 2003). It is already known that there is a positive correlation between increased frequency of $\mathrm{MN}$ and the appearance of tumors in rodents and humans (Clare et al. 2006, Azevedo et al. 2003). 
Thus, considering the widespread use of this plant by the Brazilian population, the present work aimed at evaluating the cytotoxic, genotoxic, and antigenotoxic activities of Celtis iguanaea aqueous leaf extract (CALE) using the in vivo mouse bone marrow micronucleus test.

\section{MATERIALS AND METHODS}

Plant Material: Celtis iguanaea Extract

Celtis iguanaea (Jacq.) Sargent (“esporão de galo") leaves were collected in a riparian forest located in the municipality of Campestre $\left(16^{\circ} 45^{\prime} 44^{\prime \prime} \mathrm{S}\right.$; $49^{\circ} 41^{\prime} 40^{\prime \prime} \mathrm{W}$; altitude $\left.=651 \mathrm{~m}\right)$, in the state of Goiás, Midwestern Region of Brazil. The botanical material was identified and a voucher specimen deposited in the Herbarium of the Universidade Federal de Goiás, Goiânia, GO, under the number 40110/UFG.

The plant material was prepared according to Paula, 2009: The leaves were dried in an oven at $40^{\circ} \mathrm{C}$ with forced ventilation and then ground into a powder. CALE was obtained by infusion of the powder at $3 \%$ at $80^{\circ} \mathrm{C}$ for $30 \mathrm{~min}$, with agitation every $10 \mathrm{~min}$. After vacuum filtration, the filtrate was concentrated under reduced pressure at $45^{\circ} \mathrm{C}$. The yield of the extract was determined by the dry weight method (20\%), and the final concentration was $60 \mathrm{mg} \cdot \mathrm{mL}^{-1}$. At this concentration, CALE showed $\mathrm{pH}$ of 7.22 , was odorless, had a greenish aspect and presented mild viscosity, probably due to the presence of mucilage. CALE solutions were always prepared with distilled water (extract concentrations of 100,300 , and $500 \mathrm{mg} \cdot \mathrm{kg}^{-1}$ ) immediately before their use in the experiments.

\section{ANIMALS}

This study was approved by the Human and Animal Research Ethics Commitee of the Universidade Federal de Goiás (CEPMHA/HC/UFG n 014/09). Healthy young male adults (8-12 weeks) outbred mice (Mus musculus, Swiss Webster), weighing 30-
$40 \mathrm{~g}$, obtained from the Central Animal Facility of Universidade Federal de Goiás (Goiás, Brazil) were randomly allocated to treated groups. All animals were brought to the laboratory 7 days before the experiments and housed in polyethylene cages (40 $\mathrm{cm} \times 30 \mathrm{~cm} \times 16 \mathrm{~cm}$ ), in groups of five animals, lined with wood shavings, in air-conditioned rooms at $25 \pm 2{ }^{\circ} \mathrm{C}$ and $50 \pm 10 \%$ relative humidity, with a 12-h light/dark natural cycle. Food (appropriate commercial rodent diet Labina, Ecibra Ltda.) and water were given ad libitum.

\section{EXPERIMENTAL PROCEDURE}

To evaluate the genotoxicity of the extract, five animal groups were orally treated with three different doses (100, 300, and $500 \mathrm{mg} \cdot \mathrm{kg}^{-1}$ body weight) of CALE. A positive control group (4 mg. $\mathrm{kg}^{-1}$ i.p. mitomycin $\mathrm{C}, \mathrm{C}_{15} \mathrm{H}_{18} \mathrm{~N} 4 \mathrm{O} 5$, MMC, Bristol-Myers Squibb) and another negative (sterile distilled water) control group were included. In order to assess antigenotoxicity, the same CALE doses were administered simultaneously with a single i.p. dose of MMC $\left(4 \mathrm{mg} \cdot \mathrm{kg}^{-1}\right)$. All treatments were evaluated $24 \mathrm{~h}$ and $48 \mathrm{~h}$ after administration except for the negative control ( $24 \mathrm{~h})$. The animals were euthanized by cervical dislocation, femurs were dissected, opened, and the bone marrow was gently flushed out using fetal calf serum (Soralli). After homogenization of the bone marrow in serum, it was centrifuged at 1,000 rpm for $5 \mathrm{~min}$. The bone marrow cells were smeared on glass slides, coded for blind analysis, air-dried, and fixed with absolute methanol $\left(\mathrm{CH}_{4} \mathrm{O}\right.$, LabSynth) for $5 \mathrm{~min}$. The smears were stained with Giemsa (Doles), dibasic sodium phosphate $\left(\mathrm{Na}_{2} \mathrm{HPO}_{4} 12 \mathrm{H}_{2} \mathrm{O}, \quad\right.$ Sigma-Aldrich Chemical Co.), and monobasic sodium phosphate $\left(\mathrm{NaH}_{2} \mathrm{PO}_{4} \mathrm{H}_{2} \mathrm{O}\right.$, Sigma-Aldrich Chemical Co. $)$ to detect micronucleated polychromatic erythrocytes (MNPCE). For each mouse, three slides were prepared and a minimum of 2,000 polychromatic erythrocytes (PCE) were counted to determine the frequency of MNPCE. To evaluate CIE cytotoxicity, 
1,000 normocromatic erythrocytes (NCE) were counted, as well as the frequency of polycromatic erythrocytes (PCE) within the same microscope fields, and the PCE/NCE ratio was then calculated to measure bone marrow toxicity. The slides were analyzed by microscopy (Olympus BH-2 10x100). The micronucleus test and MNPCE scoring were carried out according to Schmid (1975).

\section{STATISTICAL ANALYSIS}

To evaluate the genotoxic activity of CALE, the frequency of MNPCE in the treated groups was compared to the results of the negative control group (genotoxicity assessment) or to the results from the positive control group (antigenotoxicity evaluation), using one-way analysis of variance (ANOVA), followed by the multiple comparison test (Tukey). $\mathrm{P}$ values lower than $0.05(p<0.05)$ were considered indicative of statistical significance. In order to assess CALE cytotoxicity, the polychromatic/ normochromatic erythrocytes ratio (PCE/NCE) of all treated groups was compared to the result of the negative control group (cytotoxicity assessment) or to the result of the positive control group (anticytotoxicity evaluation), using quisquare test $\left(\chi^{2}\right)$. A value of $p<0.05$ was taken as the criterion of statistical significance.

\section{RESULTS}

Table I summarizes the frequencies of MNPCE and $\mathrm{PCE} / \mathrm{NCE}$ ratio in mouse bone marrow cells treated with CALE.

The results obtained showed no significant increase in MNPCE frequency either $24 \mathrm{~h}$ $(4.6,5.0,5.4)$ or $48 \mathrm{~h}(4.8,5.4,4.8)$ after the administration of CALE at any tested dose (100, $300,500 \mathrm{mg} \cdot \mathrm{kg}^{-1}$ ) when compared to the negative control $(p>0.05)$. There was significant increase of MNPCE frequency in the positive control group compared to the negative control group $(p<0.05)$. This result was already expected, since MMC is described as a highly genotoxic and mutagenic agent (Kang et al. 2006).

TABLE I

MNPCE frequencies and PCE/NCE ratio in mouse bone marrow cells treated with Celtis iguanaea aqueous extract (CALE) at different doses and times.

\begin{tabular}{|c|c|c|c|c|c|c|c|c|}
\hline \multirow{2}{*}{ Treatment $\left(\mathrm{mg} \cdot \mathrm{kg}^{-1}\right)$} & \multirow{2}{*}{ Time (h) } & \multicolumn{6}{|c|}{$M N / 2000 P C E$} & \multirow{2}{*}{ PCE/NCE ratio ${ }^{4}$} \\
\hline & & \multicolumn{5}{|c|}{ Individual data } & $M e a n \pm S D^{4}$ & \\
\hline Negative control $^{1}$ & 24 & 5 & 4 & 6 & 4 & 4 & $4.60 \pm 0.89 a$ & $1.13 \pm 0.10 \mathrm{~d}$ \\
\hline \multirow{2}{*}{ Positive control $^{2}$} & 24 & 36 & 29 & 34 & 31 & 33 & $32.60 \pm 2.70 b$ & $0.51 \pm 0.04 \mathrm{e}$ \\
\hline & 48 & 14 & 12 & 11 & 11 & 15 & $12.60 \pm 1.81 \mathrm{c}$ & $0.39 \pm 0.03 \mathrm{f}$ \\
\hline \multicolumn{9}{|l|}{$\mathrm{CALE}^{3}$} \\
\hline $100 \mathrm{mg} \cdot \mathrm{kg}^{-1}$ & 24 & 4 & 7 & 3 & 4 & 5 & $4.60 \pm 1.51 \mathrm{a}$ & $1.22 \pm 0.08 \mathrm{~d}$ \\
\hline $300 \mathrm{mg} \cdot \mathrm{kg}^{-1}$ & 24 & 5 & 5 & 6 & 4 & 5 & $5.00 \pm 0.70 \mathrm{a}$ & $1.08 \pm 0.04 \mathrm{~d}$ \\
\hline $500 \mathrm{mg} \cdot \mathrm{kg}^{-1}$ & 24 & 7 & 4 & 4 & 6 & 6 & $5.40 \pm 1.34 \mathrm{a}$ & $1.18 \pm 0.07 \mathrm{~d}$ \\
\hline 100 mg.kg ${ }^{-1}$ & 48 & 3 & 6 & 4 & 5 & 6 & $4.80 \pm 1.30 \mathrm{a}$ & $1.13 \pm 0.05 \mathrm{~d}$ \\
\hline $300 \mathrm{mg} \cdot \mathrm{kg}^{-1}$ & 48 & 6 & 7 & 4 & 7 & 3 & $5.40 \pm 1.81 \mathrm{a}$ & $1.16 \pm 0.07 \mathrm{~d}$ \\
\hline $500 \mathrm{mg} \cdot \mathrm{kg}^{-1}$ & 48 & 5 & 3 & 4 & 5 & 7 & $4.80 \pm 1.48 a$ & $1.27 \pm 0.15 \mathrm{~d}$ \\
\hline
\end{tabular}

\footnotetext{
${ }^{1}$ Sterile distilled water.

${ }^{2}$ Mitomycin C (4 mg. $\left.\mathrm{kg}^{-1}\right)$.

${ }^{3}$ CALE doses are compared to their respective positive controls at the same exposure times.

${ }^{4}$ Same symbols in the same column $-p>0.05$; different symbols in the same column $-p<0.05$.
} 
Regarding cytotoxicity, no significant decrease in the PCE/NCE ratio was observed when comparing mice treated with CALE with the negative control group for all tested doses and different times of evaluation $(p>0.05)$. As expected, the PCE/NCE value of MMC was much lower compared to the negative control or
CALE doses, confirming its well-known cytotoxic activity (Estrem and Vanleeuwen 2000, Kraut and Drnovsek-Olup 1996).

Table II summarizes the frequency of MNPCE and PCE/NCE ratio in mice bone marrow cells treated simultaneously with different doses of CALE and $4.0 \mathrm{mg} \cdot \mathrm{kg}^{-1}$ of MMC.

TABLE II

MNPCE frequencies and PCE/NCE ratio after simultaneous treatment with Celtis iguanaea extract (CALE) and mitomycin C (MMC).

\begin{tabular}{|c|c|c|c|c|c|c|c|c|}
\hline \multirow{3}{*}{$\begin{array}{l}\text { Treatment }\left(\mathrm{mg} \cdot \mathrm{kg}^{-1}\right) \\
\text { Negative control }^{1}\end{array}$} & \multirow{3}{*}{$\frac{\text { Time }(h)}{24}$} & \multicolumn{6}{|c|}{$M N / 2000 P C E$} & \multirow{3}{*}{$\frac{P C E / N C E \text { ratio }}{4}$} \\
\hline & & \multicolumn{5}{|c|}{ Individual data } & \multirow{2}{*}{$\begin{array}{l}\text { Mean } \pm S D^{4} \\
4.60 \pm 0.89 \mathrm{a}\end{array}$} & \\
\hline & & 5 & 4 & 6 & 4 & 4 & & \\
\hline \multirow{2}{*}{ Positive control $^{2}$} & 24 & 36 & 29 & 34 & 31 & 33 & $32.60 \pm 2.70 b$ & $0.51 \pm 0.04 \mathrm{~b}$ \\
\hline & 48 & 14 & 12 & 11 & 11 & 15 & $12.60 \pm 1.81 \mathrm{c}$ & $0.39 \pm 0.03 c$ \\
\hline \multicolumn{9}{|l|}{$\mathrm{CALE}^{3}$} \\
\hline $100 \mathrm{mg} \cdot \mathrm{kg}^{-1}+\mathrm{MMC}$ & 24 & 24 & 26 & 27 & 21 & 22 & $24.0 \pm 2.54 \mathrm{~d}$ & $0.64 \pm 0.07 \mathrm{a}$ \\
\hline $300 \mathrm{mg} \cdot \mathrm{kg}^{-1}+\mathrm{MMC}$ & 24 & 21 & 21 & 25 & 24 & 20 & $22.2 \pm 2.16 \mathrm{~d}$ & $0.71 \pm 0.09 \mathrm{a}$ \\
\hline $500 \mathrm{mg} \cdot \mathrm{kg}^{-1}+\mathrm{MMC}$ & 24 & 23 & 20 & 19 & 20 & 18 & $20.0 \pm 1.87 \mathrm{~d}$ & $0.69 \pm 0.06 \mathrm{a}$ \\
\hline $100 \mathrm{mg} \cdot \mathrm{kg}^{-1}+\mathrm{MMC}$ & 48 & 10 & 8 & 9 & 11 & 10 & $9.60 \pm 1.14 \mathrm{e}$ & $0.58 \pm 0.07 f$ \\
\hline $300 \mathrm{mg} \cdot \mathrm{kg}^{-1}+\mathrm{MMC}$ & 48 & 9 & 8 & 8 & 9 & 8 & $8.40 \pm 0.54 \mathrm{e}$ & $0.55 \pm 0.06 f$ \\
\hline $500 \mathrm{mg} \cdot \mathrm{kg}^{-1}+\mathrm{MMC}$ & 48 & 8 & 7 & 10 & 7 & 9 & $8.20 \pm 1.30 \mathrm{e}$ & $0.62 \pm 0.04 f$ \\
\hline
\end{tabular}

${ }^{1}$ Sterile distilled water.

${ }^{2}$ Mitomycin C (4 mg.kg $\left.{ }^{-1}\right)$.

${ }^{3}$ CALE doses are compared to their respective positive controls at the same exposure times.

${ }^{4}$ Same symbols in the same column $-p>0.05$; different symbols in the same column $-p<0.05$.

The results of the antigenotoxicity evaluation showed that CALE significantly decreased MNPCE frequency either $24 \mathrm{~h}(24.0,22.2,20.0)$ or $48 \mathrm{~h}$ $(9.60,8.40,8.20)$ after the administration of any of the three tested doses $\left(100,300,500 \mathrm{mg} \cdot \mathrm{kg}^{-1} \mathrm{~g}\right.$ co-treated with MMC) compared with the positive control $(p<0.05)$.

In relation to the anticytotoxic assessment of CALE, we observed an attenuation of the cytotoxic action provoked by MMC at all tested doses, either $24 \mathrm{~h}$ or $48 \mathrm{~h}$ after exposure when compared with the respective positive control $(p<0.05)$.

\section{DISCUSSION}

In the present study, we aimed to evaluate the cytotoxic, genotoxic, and antigenotoxic activities of CALE using the mouse bone marrow micronucleus test. This short-term assay is recommended by regulatory agencies all over the world as the first in vivo test to be conducted in chemical safety analyses (Khrishna and Hayashi 2000). It has proven to be a reliable method to investigate the genotoxic (clastogenic and/or aneugenic) effects of chemical and physical agents (Hayashi et al. 1990, Schmid 1976). 
MN appear in erythrocytes due to damage induced in parental cells (Fenech 2000). These small masses of chromatin are originated from acentric fragments or lagging chromosomes that fail to incorporate into one of the daughter nuclei during telophase of the mitotic cells. MN frequency in polychromatic erythrocytes (PCE) of mouse bone marrow is a very sensitive index of damage (Suzuki et al. 2008), being induced by oxidative stress, exposure to clastogenic or aneugenic agents, genetic defects in cell cycle checkpoints, and/or DNA repair genes, and also by the deficiency of nutrients required as co-factors in DNA metabolism and chromosome segregation machinery (Bonassi et al. 2007). All of these events that cause $\mathrm{MN}$ formation are associated with the chromosomal instability commonly observed in cancer (Rajagopalan et al. 2004, Fenech 2002).

The results of the present work demonstrate that CALE did not provoke a significant increase in MNPCE frequency when compared with the negative control at all tested doses and times of exposure, indicating that this extract did not exhibit genotoxic effects in PCE of mouse bone marrow.

The micronucleus assay also detects cytotoxic effects by the PCE/NCE ratio. When normal proliferation of bone marrow cells is affected by a toxic agent, there is a decrease in the number of immature erythrocytes (PCE) in relation to the number of mature erythrocytes (NCE), reflecting bone marrow toxicity and cell depression (Shahrim et al. 2006).

Our results showed no significant reduction of the PCE/NCE ratio at any CALE doses and times of exposure compared with the negative control. Therefore, these results indicate that CALE did not present cytotoxic action.

The results of the antigenotoxicity evaluation (CALE + MMC) showed that CALE significantly reduced the frequency of MMCinduced MNPCE at all concentrations tested and times of exposure, attenuating the genotoxic activity of the alkylating agent.
In relation to the anticytotoxic activity of CIE, we observed an attenuation of MMC cytotoxic action at all CALE doses and times of exposure tested.

The phytochemical analysis of Celtis iguanaea leaves revealed the presence of coumarins, mucilage, and flavonoids (Paula 2009).

Coumarins present a wide variety of bioactivities, including anti-inflammatory, anticoagulant, antimicrobial, vasodilating, anthelmintic, sedative, hypnotic, analgesic, hypothermic, and antitumorpromoting activity (García-Argáez et al. 2000, Fujioka et al. 1999, O'Kennedy and Thornes 1997, Mizuno et al. 1994). The majority of tests for assessing mutagenic and genotoxic potential suggest that coumarins are not genotoxic agents, and exposure to coumarins from food, medicines, and/or cosmetic products poses no health risks to humans (Lake 1999). However, possible phototoxic effects of coumarin furanoderivatives should be kept in mind (Edwards et al. 1994).

Mucilage is used in medicine mainly as an emollient and a demulcent, but some mucilaginous plants have other applications, such as Aloe vera gel, which has been used since ancient times to treat burns and other wounds due to its ability to enhance the healing rate and to reduce the risk of infection (Choy and Chung 2003, Capasso et al. 1998).

Flavonoids have been recognized to possess anti-inflammatory, analgesic, antiallergic, hepatoprotective, anti-bacterial, antiviral, and anticarcinogenic activities (Havsteen 2002, Hodek et al. 2002). Although the mechanisms of flavonoid protection against DNA damage and potential protection against carcinogenesis are largely unknown, it is suggested that they may act as antioxidant, free radical scavengers, inhibitors of tumor cell growth, inducers of apoptosis, modulators of DNA repair, or carcinogen inactivators (Lee et al. 2003, Duthie and Dobson 1999).

Antioxidant agents are broadly known to significantly reduce cytotoxicity and genotoxicity 
of compounds that generate free radicals (Borek 2005, Halliwell 2002, Marnett 2000). It is also known that the hazardous effect of MMC is related to its ability to alkylate DNA and produce reactive free radicals, causing different types of cellular damage, including DNA breaks (Kang et al. 2006). Consequently, the antigenotoxic and anticytotoxic activities of CALE detected in our experiments can be associated, at least partially, to the presence of flavonoids exerting protective effects by scavenging reactive oxygen, reducing alkylation and/or other antioxidant mechanisms. However, the complexity of plant extracts should not be overlooked, as the final response of a treatment using them is likely to be the result of synergistic, antagonistic, and other interactive effects among their biologically active components.

Concluding, our results in the present work indicate that CALE did not exhibit genotoxic or cytotoxic effects in mouse bone marrow micronucleus test. Nonetheless, this plant extract showed antigenotoxic and anticytotoxic effects under the experimental conditions tested.

\section{ACKNOWLEDGMENTS}

This work was supported by Conselho Nacional de Desenvolvimento Científico e Tecnológico (CNPq), Coordenação de Aperfeiçoamento de Pessoal de Nível Superior (CAPES), Fundação de Apoio à Pesquisa (FUNAPE - UFG) and Fundação de Amparo à Pesquisa do Estado de Goiás (FAPEG).

\section{AUTHOR DISCLOSURE STATEMENT}

No competing financial interests exist.

\section{RESUMO}

Levantamentos etnobotânicos de plantas nativas do cerrado evidenciam que as folhas de Celtis iguanaea (Jacq.) Sargent (Cannabaceae), popularmente conhecidas como "esporão-de-galo" são usadas na medicina popular para dores no corpo, asma, cólicas, má-digestão, infecções urinárias, disfunções renais, como estimulante ou como diurético. $\mathrm{O}$ presente trabalho teve como objetivo avaliar as possíveis atividades citotóxica, genotóxica e antigenotóxica do extrato aquoso das folhas de C. Iguanaea (CALE) através do teste do micronúcleo em medula óssea de camundongos. Para avaliar a genotoxicidade de CALE, os camundongos foram tratados por via oral com três diferentes concentrações de extrato $(100,300$ e 500 $\left.\mathrm{mg} \cdot \mathrm{kg}^{-1}\right)$. Para a investigação da atividade antigenotóxica, foram utilizadas as mesmas doses concomitantemente a uma única dose i.p. de Mitomicina C (MMC, 4mg. $\mathrm{kg}^{-1}$ ). Com exceção do controle negativo (apenas 24h), todas as outras doses tiveram as frequências de eritrócitos policromáticos micronucleados (EPCMN) avaliadas em 24 e 48 horas após o tratamento. A Genotoxicidade foi avaliada por meio da frequência de eritrócitos policromáticos micronucleados (MNPCE), enquanto que a citotoxicidade foi mensurada pela razão entre eritrócitos policromáticos e normocromáticos (PCE / NCE). Os resultados mostraram que CALE não apresentou uma redução significativa na razão $\mathrm{PCE} / \mathrm{NCE}$, nem um aumento considerável na frequência de EPCMN. No entanto, CALE reduziu a toxicidade na medula óssea (aumento na razão PCE/NCE) e diminuiu a frequência de micronúcleos induzidos pela MMC. Nos resultados obtidos, CALE não apresentou efeitos citotóxicos e genotóxicos, contudo apresentou ações antigenotóxicas e anticitotóxicas nas condições experimentais aplicadas neste estudo.

Palavra-chave: Citotoxicidade, genotoxicidade, camundongos, planta medicinal.

\section{REFERENCES}

ARUOMA O. 2003. Methodological considerations for characterizing potential antioxidant actions of bioactive components in plant foods. Mutat Res 523-524: 9-20.

Azevedo L, Gomes JC, Stringheta PC, Gontijo AMMC, PADOVANI CR, RIBEIRO LR AND SALVADORI DMF. 2003. Black bean (Phaseolus vulgaris L.) as a protective agent against DNA damage in mice. Food Chem Toxicol 41: 1671-1676.

Bolognesi C, LANDini E, Perrone E And Roggieri P. 2004. Cytogenetic biomonitoring of a floriculturist population in Italy: micronucleus analysis by fluorescence in situ hybridization (FISH) with an all-chromosome centromeric probe. Mutat Res 557: 109-117. 
BONASSI S ET AL. 2007. An increased micronucleus frequency in peripheral blood lymphocytes predicts the risk of cancer in humans. Carcinogenesis 28: 625-631.

BOREK C. 2005. Antioxidants and the prevention of hormonally regulated cancer. J Men's Health Gender 2: 346-352.

Capasso F, Borrelli F, CAPAsso R, Di Carlo G, Izzo AA, Pinto L, MAscolo N, CASTAldo S AND LONGO R. 1998. Aloe and its therapeutic use. Phytother Res 12: S124-S127.

CARNEIRO MRB. 2009. A flora medicinal no centro oeste do Brasil: um estudo de caso com abordagem etnobotânica em Campo Limpo de Goiás. Master's Dissertation, UniEVANGÉLICA, Anápolis, Brasil. (Unpublished).

CHOY S AND CHUNG MH. 2003. A review on the relationship between aloe vera components and their biological effects. Semin Integr Med 1: 53-62.

CHOY WN. 2001. Regulatory genetic toxicology tests. In: Genetic toxicology and cancer risk assessment, p. 93-113.

ChUnG HW, Kang SJ AND KIM SY. 2002. A combination of the micronucleus assay and a FISH technique for evaluation of the genotoxicity of 1,2,4-benzenetriol. Mutat Res 516: 49-56.

CLARE MG ET AL. 2006. SFTG international collaborative study on in vitro micronucleus test II. Using human lymphocytes. Mutat Res 607: 37-60.

DÉCIGA-CAMPOS M, RIVERO-CRUZ I, ARRIAGA-AlbA M, Castaneda-Corral G, ANGELes-López GE, NAVARRETE A AND MATA R. 2007. Acute toxicity and mutagenic activity of mexican plants used in traditional medicine. $\mathrm{J}$ Ethnopharmacol 110: 334-342.

DING GR, NAKAHARA T AND MIYAKOSHI J. 2003. Induction of kinetochore-positive and kinetochore-negative micronuclei in CHO cells by ELF magnetic fields and/or X-rays. Mutagenesis 18: 439-443.

DUTHIE SJ AND DoBSON VL. 1999. Dietary flavonoids protect human colonocyte DNA from oxidative attack in vitro. Eur J Nutr 38: 28-34.

EDWARDS SM, DONNELlY TA, SAYRE RM, RHEINS LA, SPIELMANN H AND LIEBSCH M. 1994. Quantitative in vitro assessment of phototoxicity using a human skin model, Skin2. Photodermatol Photoimmunol Photomed 10: 111117.

ESTREM SA AND VANLEEUWEN RN. 2000. Use of mitomycin-C for maintaining myringotomy patency. Otolaryngol Head Neck Surg 122: 8-10.

FEARON ER AND VolgelsteIn B. 1990. A genetic model for colorectal tumorigenesis. Cell 61: 759-767.

FENECH M. 2000. The in vitro micronucleus technique. Mutat Res 455: 81-95.

FENECH M. 2002. Biomarkers of genetic damage for cancer epidemiology. Toxicology 181-182: 411-416.

FUJIOKA T, FURUMi K, FUJII H, OKaBE H, Mihashi K, NAKANO Y, MATSUNAGAH, KATANO MAND MORI M. 1999. Antiproliferative constituents from umbelliferae plants. V. A new furanocoumarin and falcarindiol furanocoumarin ethers from the root of Angelica japonica. Chem Pharm Bull 47: 96-100.
GARCÍA-ArgÁEZ AN, Ramírez Apan TO, PARRA DElgado H, VelázQuez G AND MARTíneZ-VÁzQuez M. 2000. Anti-inflammatory activity of coumarins from Decatropis bicolor on TPA ear mice model. Planta Med 66: 279-281.

GaUthier JM, Dubeau H, RASSART E, JARMAN WM AND WELLS RS. 1999. Biomarkers of DNA damage in marine mammals. Mutat Res 444: 427-439.

Gupta CP, Dubey RC, KANG SC AND MAHESWARI DK. 2001. Antibiosis mediated necrotrophic effect of Pseudomonas GRC2 against two fungal plant pathogens. Curr Sci 81: 91-94.

HALBERSTEIN RA. 2005. Medicinal plants: historical and crosscultural usage patterns. Annals of Epidemiology 15: 686699.

HALliWELl B. 2002. Effect of diet on cancer development: is oxidative DNA damage a biomarker? Free Rad Biol Med 32: 968-974

HAVSTEEN BH. 2002. The biochemistry and medical significance of flavonoids. Review article, Pharmacol Therapeut 96: 67-202.

HaYashi M, Morita T, Kodama Y, SOFUnI T AND ISHIDATE JR M. 1990. The micronucleus assay with mouse peripheral blood reticulocytes using acridine orange-coated slides. Mutat Res 245: 245-249.

HodeK P, TREFIL P AND STIBOROVÁ M. 2002. Flavonoids: potent and versatile biologically active compounds interacting with cytochromes P450. Chem Biol Interact 139: 1-21.

IZZOTtI A, BALANSKy RM, DAgOSTINI F, BenNiCelli C, Myers SR, Grubbs CJ, Lubet RA, Kelloff GJ AND DE FLORA S. 2001. Modulation of biomarkers by chemopreventive agents in smoke-exposed rats. Cancer Res 61: 2472-2479.

KANG YH, LeE KA, RYU CJ, LEe HG, Lim JS PARK SN, PAIK SG AND YoOn DY. 2006. Mitomycin C induces apoptosis via Fas/FasL dependent pathway and suppression of IL-18 in cervical carcinoma cells. Cancer Lett 237: 33-44.

KHRISHNA G AND HAYASHI M. 2000. In vivo rodent micronucleus assay: protocol, conduct and data interpretation. Mutat Res 455: 155-166.

KRAUT A AND DRNOVSEK-OLUP B. 1996. Instillation of mitomycin-C after recurrent pterygium surgery. Eur J Ophthalmol 6: 264-267.

LAKE BG. 1999. Coumarin metabolism, toxicity and carcinogenicity: relevance for human risk assessment. Food Chem Toxicol 37: 423-453.

LeE JC, Kim J, PARK JK, ChUng GH AND JANG YS. 2003. The antioxidant, rather than prooxidant, activities of quercetin on normal cells: quercetin protects mouse thymocytes from glucose oxidase-mediated apoptosis. Exp Cell Res 291: 386-397.

Llorente MT, Martos A AND CAstano A. 2002. Detection of cytogenetic alterations and blood cell changes in natural populations of carp. Ecotoxicology 11: 27-34. 
Machado RB, Aguiar LMS, CASTRo AJF AND Nogueira C. 2008. Caracterização da fauna e flora do Cerrado. In: Palestras do XI Simpósio Nacional sobre o Cerrado e II Simpósio Internacional sobre Savanas Tropicais, 12-17 outubro, Brasília, DF, Brasil.

Maciel MAM, Pinto AC, VEIGA JÚNIOR VF, GRYNBERG NF AND ECHEVARRIA A. 2002. Plantas medicinais: a necessidade de estudos multidisciplinares. Quim Nova 25(3): 429-438.

Majer BJ, LAKy B, KNASMUller S AND Kassie F. 2001. Use of the micronucleus assay with exfoliated epithelial cells as a biomarker for monitoring individuals at elevated risk of genetic damage and in chemoprevention trials. Mutat Res 489: 147-172.

MARNETT LJ. 2000. Oxyradicals and DNA damage. Carcinogenesis $21: 361-370$.

Marques RCP, Medeiros SRB, Dias CS, Barbosa-Filho JMAND AGNEZ-LIMALF. 2003. Evaluation of the mutagenic potential of yangambin and of the hydroalcoholic extract of Ocotea duckei by the Ames test. Mutat Res 536: 117-120.

Mateuca R, Lombaert N, AKA PV, Decordier I AND KIRSCH-VOLDERS M. 2006. Chromosomal changes: induction, detection methods and applicability in human biomonitoring. Biochimie 88: 515-1531.

MizUnO A, TAKata M, OKADA Y, OKUMAYA T, Nishino H, NISHINO A, TAKAYASU J AND IWASHIMAA. 1994. Structures of new coumarins and anti-tumor-promoting activity of coumarins from Angelica edulis. Planta Med 60: 333-336.

Myers N, MitTermeier RA, MitTermeier CG, FonsecA GAB AND KENT J. 2000. Biodiversity hotspots for conservation priorities. Nature 403: 853-858.

O'KenNEDY R AND THORNES RD. 1997. Coumarins - biology, applications and mode of action. J Wiley \& Sons, New York.

PAULA MA. 2009. Caracterização farmacognóstica e estudo das atividades farmacológicas do extrato aquoso do esporão de galo (Celtis iguanaea (Jacq.) Sargent). Master's Dissertation, Faculdade de Farmácia, Universidade Federal de Goiás, Goiânia, Brasil. (Unpublished).

Piliackas VDD, Piliackas JM, Barbosa LM, Silva JR JL AND CANUTO MH. 2001. Análise etnobotânica das plantas medicinais e sua influência sobre o ambiente da cidade de Diamantina, Minas Gerais (MG), Brasil. Public Avulsas Instituto Pau Brasil Vol. 10.

Rajagopalan H, Jallepalli PV, Rago C, Velculescu VE, KinZler KW, Vogelstein B And Lengauer C. 2004. Inactivation of hCDC4 can cause chromosomal instability. Nature 428: 77-81.
RASKIN I ET AL. 2002. Plants and human health in the twentyfirst century. Trends in Biotechnology 20, 12: 522-531.

RATES SMK. 2001. Plants as source of drugs. Toxicon 39: 603-613.

RoY M, CHAKRABARTY S, SINHA D, BHATTACGARYA RK AND SIDDIQ M. 2003. Anticlastogenic, antigenotoxic and apoptotic activity of epigallocatechin gallate: a green tea polyphenol. Mutat Res 523-524: 33-41.

SCHMID W. 1975. The micronucleus test. Mutat Res 31: 9-15.

SCHMID W. 1976. The micronucleus test for cytogenetic analysis. In: Chemical mutagens: Principles and methods for their detection, p. 31-53.

SHAHRIM Z, BAHARUDDIN PJNM, YAHYA NA, MUHAMMAD H, BAKAR RA AND ISMAIL Z. 2006. The in vivo rodent micronucleus assay of Kacip Fatimah (Labisia pumila) extract. Trop Biomed 23: 214-219.

Silva CSP AND PROENÇA CEB. 2008. Uso e disponibilidade de recursos medicinais no município de Ouro Verde de Goiás, GO, Brasil. Acta Bot Bras 22: 481-492.

SoUZA VC AND LORENZI H. 2005. Botânica sistemática: guia ilustrado para identificação das famílias de Angiospermas da flora brasileira, baseado em APG II. Instituto Plantarum, Nova Odessa.

Suzuki Y, TAKagi R, KaWAsaki I, Matsudaira T, YANAGISAWA H AND SHIMIZU H. 2008. The micronucleus test and erythropoiesis: effects of cyclic adenosine monophosphate (cAMP) on micronucleus formation. Mutat Res 655: 47-51.

VENDRUSCOLO GS AND MENTZ LA. 2006. Estudo da concordância das citações de uso e importância das espécies e famílias utilizadas como medicinais pela comunidade do bairro Ponta Grossa, Porto Alegre, RS, Brasil. Acta Bot Bras 20: 367-382.

Verschaeve L, Kestens V, Taylor JLS, Elgorashi EE, Maes A, Van Puyelde L, Kimpe N and Van Staden J. 2004. Investigation of the antimutagenic effects of selected South African medicinal plant extracts. Toxicol In Vitro 18: 29-35.

WATERS MD, STACK HF, JACKSON MA, BROCKMAN HE AND DE FLORA S. 1996. Activity profiles of antimutagens: in vitro and in vivo data. Mutat Res 350: 109-129.

WINK M. 2009. Functions and biotechnology of plant secondary metabolites. Annu Plant Rev 39: 1-20. 